\title{
Contamination and Health Risk Assessment of Exposure to Heavy Metals in Soils from Informal E-Waste Recycling Site in Ghana
}

\author{
Vincent N. Kyere ${ }^{a *}$, Klaus Greve ${ }^{b}$, Sampson M. Atiemo ${ }^{c}$, Doris Amoako ${ }^{d}$, \\ IJ Kwame Aboh ${ }^{\mathrm{c}}$, Benjamin, S. Cheabu ${ }^{\mathrm{d}}$ \\ ${ }^{a}$ Center for Development Research, ZEF, University of Bonn, Bonn, NRW, Germany \\ ${ }^{b}$ Geography Institute, University of Bonn, Germany \\ ${ }^{c}$ Ghana Atomic Energy Commission, Ghana \\ ${ }^{d}$ Catholic University College of Ghana, Sunyani, Ghana
}

\begin{abstract}
The objective of this study is first, to investigate the level of heavy metals in soils from Agbogbloshie e-waste processing site (AEPS), the degree at which these heavy metals contaminate the area and finally, to assess the carcinogenic and non-carcinogenic health risk of heavy metals on workers and residents in around the AEPS. 132 soil samples were collected from the study area and the samples analyzed for $\mathrm{Ba}, \mathrm{Cd}, \mathrm{Co}, \mathrm{Cr}, \mathrm{Cu}, \mathrm{Hg}, \mathrm{Ni}, \mathrm{Pb}$ and $\mathrm{Zn}$ heavy metals after appropriate preparations were made. Results of the analysis showed mean concentrations of $\mathrm{Cd}, \mathrm{Cr}$ and $\mathrm{Ni}$ considered as carcinogenic were lower than permissible levels of Dutch and Canadian soil standards. Mean concentrations however of $\mathrm{Cu}, \mathrm{Pb}$ and $\mathrm{Zn}$ were between $100 \%$ and $500 \%$ higher than the permissible levels. Assessment of the degree of Contamination indicated $\mathrm{Ni}<\mathrm{Ba}<\mathrm{Co}<\mathrm{Cr}<\mathrm{Zn}<\mathrm{Hg}<\mathrm{Cu}<\mathrm{Cd}<\mathrm{Pb}$ in an increasing order as contributing to the degree of contamination with according to the degree of contamination index the burning, dismantling, residential and commercial considered as very highly contaminated. The health risk analysis of individual heavy metals in soil indicated non-carcinogenic risk of $\mathrm{Cr}, \mathrm{Hg}$ and $\mathrm{Pb}$ with hazard index above the safe level of 1 in the burning and dismantling areas and as such could trigger neurological and developmental disorders in children less than six (6) years.
\end{abstract}

\section{Keywords:}

Heavy Metals;

Degree Of Contamination;

Health Risk;

Carcinogenic;

Non-Carcinogenic.

Article History:

Received: 10 August 2018

Accepted: 15 October 2018

\section{1- Introduction}

Heavy metals are ubiquitous in the environment as a result of natural and anthropogenic activities such as discharges from industries, vehicular emission, agriculture and other human induced activities. Heavy metals from these sources accumulate in soil which not only contaminate the soil but lead to uptake of elevated heavy metals by plants and thus affect food quality and safety [1-4]. The accumulation of heavy metals in soils and plants is of increasing concern as it poses potential human health risk. Food chain contamination, inhalation of contaminated soil dust and dermal contact as three possible pathways or routes by which humans can be exposed to heavy metals. Human exposure to heavy metals can have both carcinogenic and non-carcinogenic effect and can affect kidney, damage the nervous system of children, cause blood and brain disorders, irritation to the eyes and skin and can also cause permanent eye injury damage to DNA.

The Agbogbloshie scrapyard is well known for the processing end of life or discarded electrical and electronic equipment. With increasing quantities of discarded electrical and electronic equipment and its components known to contain valuable metals, avenues have been created for informal e-waste recyclers who apply extreme crude, primitive

\footnotetext{
* CONTACT: Kyerevincent@gmail.com

DOI: http://dx.doi.org/10.28991/esj-2018-01162
}

(C) This is an open access article under the CC-BY license (https://creativecommons.org/licenses/by/4.0/). 
and rudimentary approaches such as open burning of cables and unsound dismantling to recover valuable fraction or metals from this stream of waste. The procedures of the informal recyclers and improper disposal of hazardous fractions contaminate the environment as a result of the release of heavy metals, polychlorinated biphenyls and brominated flame retardants from the open burning and unsound dismantling of e-waste in Agbogbloshie posing human health and ecological risk. Earlier studies showed significantly high levels of pollutants in soils and sediments from Agbogbloshie [5-10]. There is however very little known about the degree of contamination and health risk associated with heavy metals measured from Agbogbloshie.

Human health risk assessment models have been used to examine whether the exposure to heavy metals of any dose or amount could cause an adverse effect to human health [11-16]. Human health risk assessment consists of hazard identification, toxicity assessment, exposure assessment and characterization of risk, and involves estimating the probability of occurrence of an event (intake of heavy metals) and the probable magnitude of adverse effect of the event over a period of time [17]. With health risk especially high for children due to their low tolerance to toxins as well as the inadvertent ingestion of significant quantities of dust (or soil) through hand-to-mouth pathways [18, 19]. This research sought to fill the health risk gap by examining the degree of contamination posed by heavy metals in soil across the Agbogbloshie study site and assess both carcinogenic and non-carcinogenic health risk heavy metals in soil from the study site pose to children.

\section{2- Materials and Methods}

\section{2-1- Study Area}

Agbogbloshie is a suburb of Ghana's national capital Accra and is situated on the banks of the Korle lagoon and Odaw river northwest of the central business district between latitude $5 \circ 32^{\prime} 30^{\prime}$ ' $\mathrm{N}$ and $5 \circ 33^{\prime} 30^{\prime}$ ' $\mathrm{N}$ and on longitude $0 \circ 13$ ' 30''W. The e-waste processing site in Agbogbloshie scrapyard covers an area of 6.2 hectres and surrounding the site are areas such as food market, farms, schools, health centres and residential areas (Figure 1). Agbogbloshie has a population of about 40,000 inhabitants with the active age group of 11 to 35 years involved in e-waste recycling [6]. Agbogbloshie e-waste processing site (AEPS) nick named "graveyard" for electronic waste is the largest in Ghana with activities estimated to bring in about 105 million dollars in revenue per annum to the economy. With lack of strict legislation and regulation, the brisk and primitive approaches such as burning used in Agbogbloshie, heavy metals, Copper $(\mathrm{Cu})$, zinc $(\mathrm{Zn})$, lead $(\mathrm{Pb})$, cadmium $(\mathrm{Cd})$, mercury $(\mathrm{Hg})$, chromium $(\mathrm{Cr})$, nickel $(\mathrm{Ni})$ and other contaminants are emitted in to the environment in large quantities.

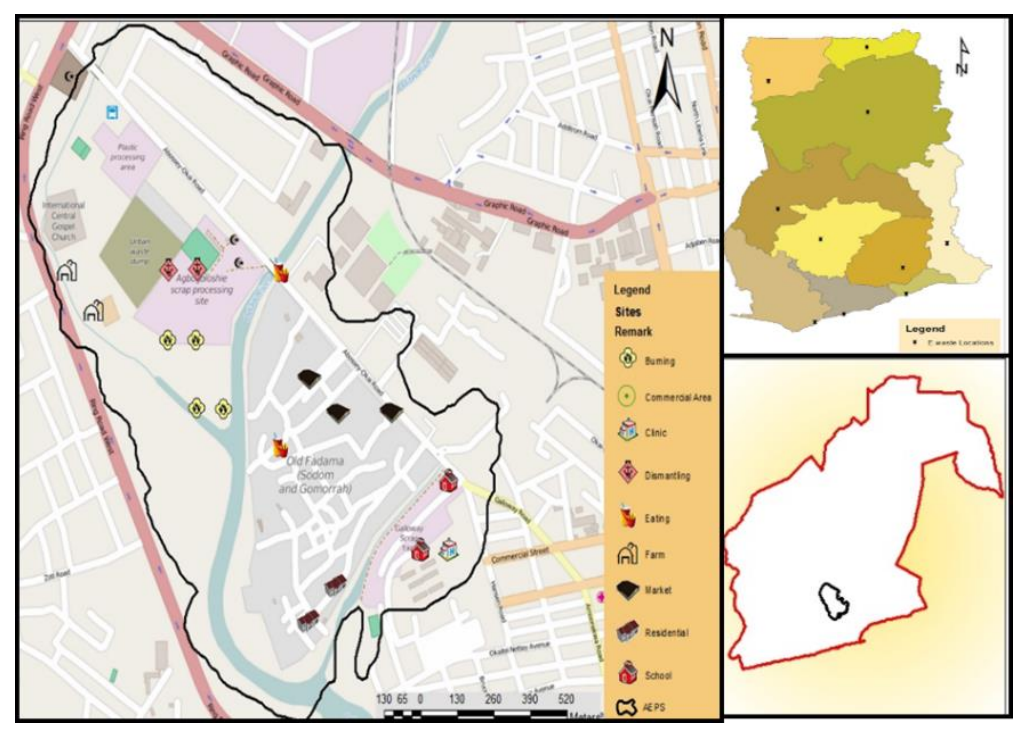

Figure 1. Location map of Agbogbloshie e-waste processing site

\section{2-2- Sample Collection, Preparation and Analysis}

132 soil samples were collected from 9 clusters in Agbogbloshie based on grid sampling system at a $100 \mathrm{~m}$ interval with the help of a handheld GPS. The samples were air dried in the laboratory at room temperature for a week. The samples were then pulverized using $100 \mu \mathrm{m}$ nylon mesh to remove debris. Using a 10 ton hydraulic press 10 grams of the pulverized samples were pressed into $2.5 \mathrm{~cm}$ diameter pellet. An x-ray fluorescence spectrometer operating at $1000 \mathrm{w}$ $(40 \mathrm{kV}$ and $20 \mathrm{~mA}$ ) was used to analyzed for heavy metals in the $2.5 \mathrm{~cm}$ pellet. The pellet samples were placed on a disk $45^{\circ}$ to the primary beam for a 10 minute irradiation using a silicon lithium $\mathrm{Si}(\mathrm{Li})$ detector at a resolution of $160 \mathrm{eV}$ with $\mathrm{Mn}$ and $\mathrm{K} \alpha$ peak. To validate the procedure used for analysis, IAEA soil 7 reference standard material was irradiated 5 
times and the mean concentration of the elements obtained compared with certified values. The results felt within acceptable ratio of 5 to $10 \%$ indicating the results of the XRF conforms to certified values of the IAEA standard reference material. Validation procedure was repeated to ensure the calibration prior to the analysis was still intact. $\mathrm{R} 3.2 .1$ software and Microsoft excel were used to conduct basic statistical analysis of the results obtained in the study

\section{2-3- Data Analysis}

\section{2-3-1- Contamination Assessment}

With the possibility to utilize background or continental crustal averages and provide comprehensive assessment of contamination, this study utilized the contamination factor (Equation 1) to evaluate the pollution of the environment by single substances and complimented by the degree of contamination (Equation 2) which is defined as the sum of contamination factors was used to describe the contamination of the environment by all examined heavy metals.

$$
\begin{aligned}
& C_{f}^{i}=\frac{C_{0-1}^{i}}{C_{n}^{i}} \\
& C_{d e g}=\sum C_{f}^{i}
\end{aligned}
$$

where $C_{f}^{i}$ is the contamination factor of the element of interest, $C_{0-1}^{i}$ is the concentration of the element in the sample, and $C_{n}^{i}$ is the background concentration or the continental crustal average as was used by [20]. $C_{f}^{i}$ is defined by the following criteria $<1$ low contamination, $1<C_{f}^{i} \leq 3$ moderate contamination, $3<C_{f}^{i} \leq 6$ Considerable contamination, and $C_{f}^{i}>6$ very high contamination. $C_{d e g}$ is the degree of contamination defined by Cdeg $<8$ as low degree of contamination, $8 \leq \mathrm{Cdeg}<16$ as moderate degree of contamination, $16 \leq \mathrm{Cdeg}<32$ as considerable degree of contamination and $\mathrm{Cdeg} \geq 32$ as very high degree of contamination.

\section{2-3-2- Determination of health risk from heavy metals}

Health risk assessment is defined as the process of estimating the probability of occurrence of an event (exposure to heavy metals) and probable magnitude of its adverse effect over a specified time period.[21, 22] The assessment of human health risk in this study consisted of three phases; the hazard identification which involves the selection of chemicals or heavy metals of concern, exposure and dose intake assessment where the possible average daily dosage (ADD) for the three exposure pathways by which humans can be contaminated estimated and then finally the characterization of the human health risk either as carcinogenic or non-carcinogenic. The ADD which is the quantity of heavy metal concentration ingested, inhaled or absorbed through the skin were estimated based on exposure to heavy metal assessment model [23]. The equations of the exposure assessment models are as follows:

\section{Ingestion}

$$
A D D_{\text {ing }}=C(\mathrm{mg} / \mathrm{kg}) \times \frac{\operatorname{IngR} \times E F \times E D}{B W \times A T} \times 10^{-6}
$$

\section{Dermal contact}

$$
A D D_{\text {derm }}=C(\mathrm{mg} / \mathrm{kg}) \times \frac{S A \times S L \times A B S \times E F \times E D}{B W \times A T} \times 10^{-6}
$$

\section{Inhalation}

$$
A D D_{\text {inh }}=C(m g / k g) \times \frac{I n h R \times E F \times E D}{P E F \times B W \times A T}
$$

The characterization of the human health risk is expressed by the hazard index (Equation 7) and hazard quotient (Equation 6), with the hazard quotient defined as a ratio between exposure, i.e, the ADD for per exposure pathway of the heavy metal and the reference dose of the heavy metal. The sum of the hazard quotient for all the three exposure pathways defined the non-carcinogenic health risk.

$$
\begin{aligned}
& H Q=\frac{D I}{R f D} \\
& H I=H Q(\text { inh })+H Q(\text { ing })+H Q(\text { derm })
\end{aligned}
$$

Where the parameters in the Equations 3-7 are defined as follows for children less than 6 years; IngR: ingestion rate given as $200 \mathrm{mg}$ day-1; InhR: inhalation rate $7.6 \mathrm{~m} 3 \mathrm{day}-1$; EF: exposure frequency as 350 day year-1; ED: exposure duration as 6 years; SA: Skin area exposed as $2800 \mathrm{~cm} 2$; SL: skin adherence factor as $0.2 \mathrm{mg} \mathrm{cm}-2 \mathrm{~h}-1$; ABS: dermal absorption factor as 0.001 for all heavy metals; PEF: particle emission factor as $1.36 \times 109 \mathrm{~m} 3 \mathrm{~kg}-1$; BW: average body weight as $15 \mathrm{~kg}$ for Ghanaian children and AT: averaging time; for non-carcinogens, ED $\times 365$ days; for carcinogens, 
$70 \times 365=25,550$ days. For carcinogens, the lifetime average daily dose (LADD) (Equation 8) for inhalation exposure was used in the assessment of the cancer risk [24,25]. The LADD is expressed as:

$$
L A D D=\frac{C \times E F}{A T \times P E F} \times\left[\left(\frac{I n h R_{\text {child }} \times E D_{\text {child }}}{B W_{\text {child }}}\right)+\left(\frac{I n h R_{\text {adult }} \times E D_{\text {adult }}}{B W_{\text {adult }}}\right)\right]
$$

The potential cancer health risk was obtained by the product of the lifetime average daily dose and the inhalation slope factors for each of the heavy metals.

\section{3- Results and Discussion}

\section{3-1- Heavy Metal Concentration in Soils}

Concentrations of heavy metals measured in soils from AEPS are summarized in Table 1. Results indicate that the mean concentrations of Ba in the burning, dismantling, residential and areas close to worship centres, as well as mean concentrations of $\mathrm{Cu}$ and $\mathrm{Pb}$ in the burning, dismantling, residential and recreational areas and that of $\mathrm{Zn}$ levels in burning, dismantling and residential areas were above action required limits of Dutch and Canadian soil regulatory standards. Mean concentrations of heavy metals considered as carcinogenic, $\mathrm{Cd}, \mathrm{Co}, \mathrm{Cr}$ and $\mathrm{Ni}$ as well as $\mathrm{Hg}$ (which is non-carcinogenic) measured in soil from all sites in the AEPS were however below the Dutch and Canadian soil regulatory limits. Further, the results reveal a high variation in the distribution heavy metal concentration within AEPS and also show that the highest concentration of the heavy metals alternating between the burning and dismantling site which could indicate variability and intensity of activities that are conducted within the study area. At the burning site, $\mathrm{Cu}, \mathrm{Pb}$ and $\mathrm{Zn}$ concentrations recorded 15, 5 and 3 times respectively more than concentrations for which action should be taken per the Dutch and Canadian soil standards. Similar trend is seen at the dismantling site where the mean concentration of $\mathrm{Cu}, \mathrm{Pb}$ and $\mathrm{Zn}$ are 8,2 and 3 times respectively more than concentrations for which action should be taken.

\begin{tabular}{|c|c|c|c|c|c|c|c|c|c|}
\hline Site & Ba & Cd & Co & $\mathrm{Cr}$ & $\mathrm{Cu}$ & $\mathbf{H g}$ & $\mathrm{Ni}$ & $\mathbf{P b}$ & $\mathbf{Z n}$ \\
\hline \multicolumn{10}{|c|}{ Burning } \\
\hline Mean & 641.5 & 10.1 & 43.8 & 171.5 & 2967.8 & 3.5 & 21.8 & 2666.4 & 1887.2 \\
\hline Range & $270.5-1279.0$ & $0.5-26.5$ & $19.6-95.05$ & $58.6-439.2$ & $72.2-8254.0$ & $0.9-9.9$ & $3.2-85.0$ & $81.2-5903.0$ & $158.2-5398.0$ \\
\hline \multicolumn{10}{|l|}{ Commercial Area } \\
\hline Mean & 493.6 & 0.6 & 29.6 & 290.9 & 157.7 & 0.35 & 6.2 & 163.9 & 516.9 \\
\hline Range & 281.8-973.7 & $0.5-6.1$ & $16.1-107.4$ & $36.9-881.0$ & $9.4-930.4$ & $0.5-2.2$ & $0.7-34.2$ & $14.2-865.3$ & 48.9-5398.0 \\
\hline \multicolumn{10}{|l|}{ Clinic } \\
\hline Mean & 581.1 & - & 28.5 & 119.3 & 40.7 & - & - & 55.8 & 220.5 \\
\hline Range & 370.4-791.8 & - & $14.3-42.6$ & $109.2-129.3$ & $39.4-42.0$ & - & - & $53.6-57.9$ & $181.1-259.9$ \\
\hline \multicolumn{10}{|l|}{ Dismantling } \\
\hline Mean & 785.7 & 7.8 & 66.1 & 419.2 & 1643.5 & 1.6 & 44.6 & 846.8 & 1939.2 \\
\hline Range & $120.6-1469.0$ & $0.5-26.1$ & $10.8-129.0$ & $53.2-1099.0$ & $27.0-5615.0$ & $0.7-9.9$ & $0.6-106.1$ & $30.2-2714.0$ & $53.1-5398.0$ \\
\hline \multicolumn{10}{|l|}{ Farm } \\
\hline Mean & 315.4 & 0.2 & 23.7 & 319.2 & 91.4 & 0.5 & 4.9 & 143.5 & 271.2 \\
\hline Range & 226.3-399.0 & 0.9 & $11.2-32.4$ & 70.3-1007.0 & $42.4-213.1$ & $1.0-1.5$ & $1.6-9.6$ & $52.1-397.6$ & $41.9-633.9$ \\
\hline \multicolumn{10}{|l|}{ Recreational } \\
\hline Mean & 443.7 & 1.87 & 36.5 & 338.6 & 762.9 & 0.5 & 14.8 & 355.2 & 700.3 \\
\hline \multicolumn{10}{|l|}{ Residential } \\
\hline Mean & 658.08 & 2.63 & 51.5 & 153.9 & 1354.6 & 1.6 & 27.2 & 896.1 & 1170.4 \\
\hline Range & $391.0-1045.0$ & $0.9-9.6$ & $13.5-129.0$ & $21.1-380.6$ & $38.3-6510.0$ & $1.0-9.9$ & $1.1-106.1$ & $48.1-5903.0$ & $194.5-4407.0$ \\
\hline \multicolumn{10}{|l|}{ School } \\
\hline Mean & 394.35 & 0.3 & 42.3 & 118.8 & 47.6 & 0.6 & 2.2 & 111.3 & 293.2 \\
\hline Range & $269.4-519.3$ & 0.5 & $39.4-45.10$ & $97.0-140.5$ & 29.3-65.8 & 0.6 & 2.2 & $48.4-174.2$ & $137.5-448.8$ \\
\hline \multicolumn{10}{|l|}{ Worship } \\
\hline Mean & 783.9 & 0.3 & 30.5 & 184.6 & 118.2 & 0.4 & 4.9 & 117.0 & 419.9 \\
\hline Range & $374.0-1306.0$ & 0.3 & $11.8-41.2$ & $59.9-372.7$ & $57.7-230.5$ & $0.6-0.7$ & $1.9-12.9$ & $64.3-218.9$ & $178.4-881.9$ \\
\hline Optimal (DSQGV) & 200 & 0.8 & 20 & 100 & 36 & 0.3 & 35 & 85 & 140 \\
\hline Action (DSQGV) & 625 & 12 & 240 & 380 & 190 & 10 & 210 & 530 & 720 \\
\hline Canadian (SQGV) & 500 & 10 & - & 64 & 63 & 7 & 50 & 140 & 200 \\
\hline
\end{tabular}

*Heavy metal concentration measured in $\left(\mathrm{mgL}^{-1}\right)$

\section{3-2- Contamination Assessment of Heavy Metals}

Contamination factor was used to evaluate the contribution of respective heavy metals to the sum of toxic units. Figure 2 shows results of contamination factors from the analyzed soil samples. On the average $\mathrm{Ni}<\mathrm{Ba}<\mathrm{Co}<\mathrm{Cr}<\mathrm{Zn}<\mathrm{Hg}<\mathrm{Cu}<\mathrm{Cd}<\mathrm{Pb}$ in an increasing contributed to the degree of contamination with $\mathrm{Pb}$ observed to have the highest contamination factor, while contamination factor of $\mathrm{Ni}$ is categorized as low, $\mathrm{Ba}$, Co and $\mathrm{Cr}$ categorized as moderate contamination factor with $\mathrm{Zn}, \mathrm{Hg}$ and $\mathrm{Cu}$ categorized as having very high contamination factor. Since individual metals can cause significant contamination to soil and ecosystem, it becomes more imperative to access their additive nature so as to examine or assess the cumulative risks [26]. The results of the cumulative risk represented by the degree of contamination is shown in Figure 2 . The degree of contamination of the sites were largely driven by $\mathrm{Pb}, \mathrm{Cd}$ and $\mathrm{Hg}$. The commercial, recreational, residential, dismantling and burning sites are all classified as very highly contaminated with degree of contamination greater than 32, while premises close to worship, farms and school sites classified as having considerable contamination with degree of contamination within the range of 16 and 32 and areas close to the community clinics classified as having moderate contamination with degree of contamination within the range of 8 and 16 (Figure 3 ). The problem of contamination to soil by heavy metals within the AEPS may become prominent when steps are to be taken to remediate the site for the ecological restoration project and more importantly the health risk these contaminated site could pose to children who play and live in these areas.

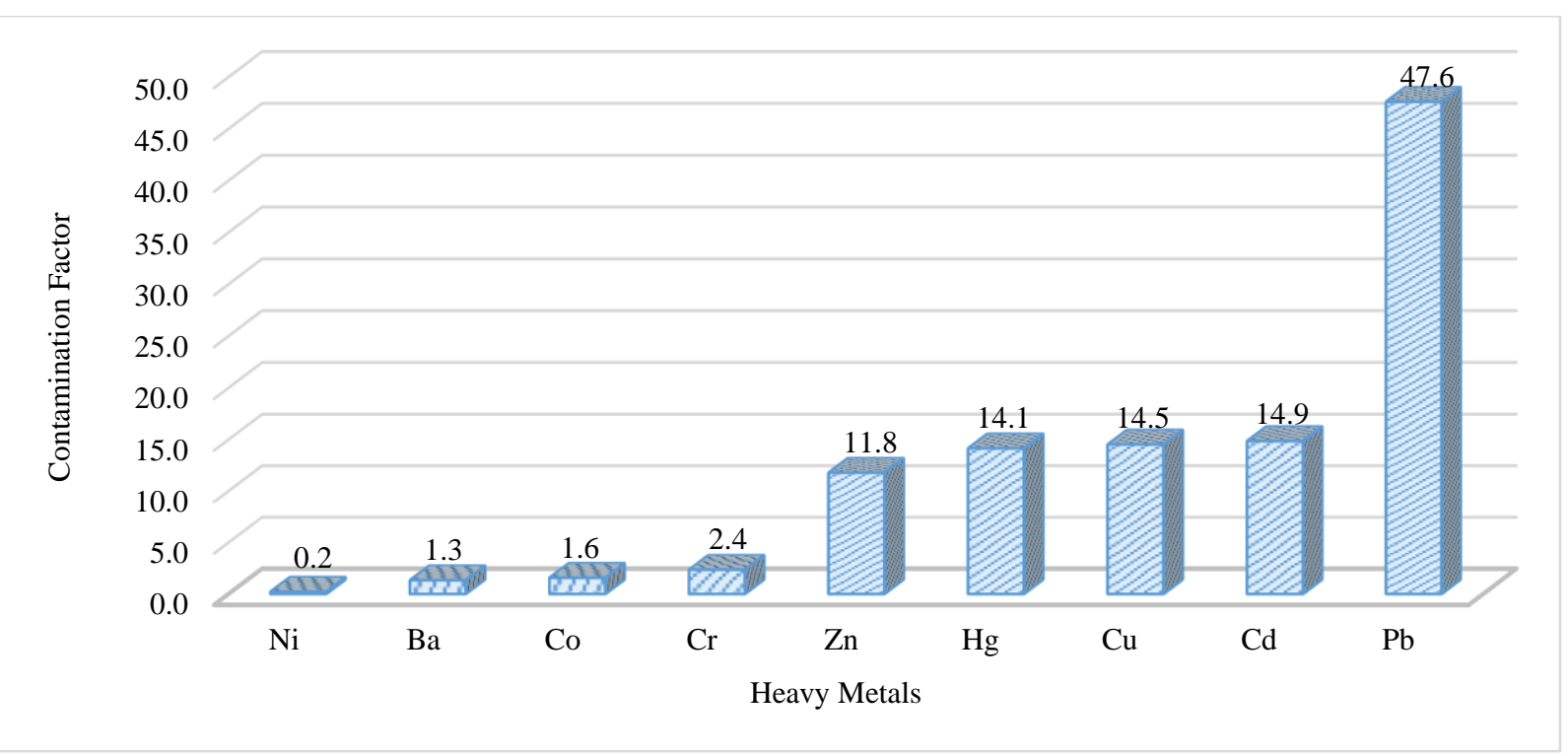

Figure 2. Contributions of respective heavy metal to the degree of contamination 


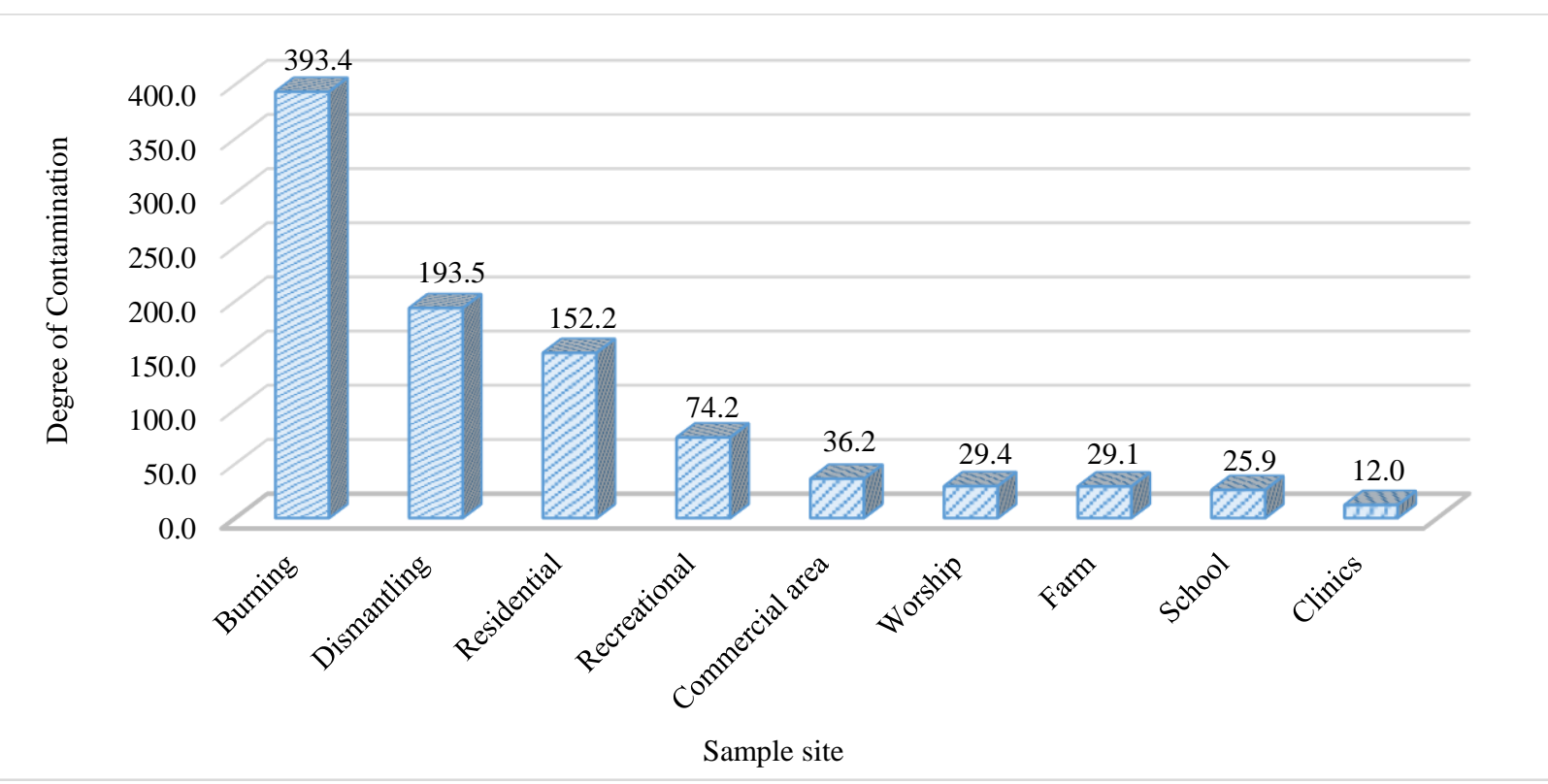

Figure 3. Degree of contamination of heavy metals from the AEPS

\section{3-3- Health Risk of Heavy Metals}

\section{3-3-1- Exposure Pathways of Heavy Metals}

The results of the health risk assessment are summarized in Table 2. The results reveal ingestion of heavy metals from soil dust as the highest exposure pathway followed by dermal intake and inhalation of heavy metals from soils. For the ingestion pathway, $\mathrm{Cr}, \mathrm{Pb}$ and $\mathrm{Ba}$ (order $\mathrm{Cr}>\mathrm{Pb}>\mathrm{Ba}$ ) were the three heavy metals with the highest hazard quotients, and a similar trend was also seen for the dermal pathway. The heavy metal $\mathrm{Cr}$ showed the highest hazard quotient through inhalation, followed by $\mathrm{Ba}$ and $\mathrm{Pb}$. It is also however worth noting that $\mathrm{Ni}$ and $\mathrm{Zn}$ had the lowest hazard quotient in all three exposure pathways. Similar exposure pathway trend of inhalation<dermal contact<ingestion have also been reported by $[11,12]$. Further, it is also worth noting that the highest exposure or possible intake of heavy metals alternate between the burning and dismantling sites indicating the activities at these sites contribute to the heavy metals measured in soil and the danger it present to children in the area.

\begin{tabular}{|c|c|c|c|c|c|c|c|c|c|}
\hline Site & Ba & Cd & Co & $\mathrm{Cr}$ & $\mathbf{C u}$ & Hg & $\mathbf{N i}$ & $\mathbf{P b}$ & $\mathbf{Z n}$ \\
\hline Ingestion RfD & 0.07 & 0.001 & 0.02 & 0.003 & 0.04 & 0.0004 & 0.02 & 0.0035 & 0.3 \\
\hline Dermal RfD & 0.0049 & 0.00001 & 0.016 & 0.00006 & 0.012 & 0.000021 & 0.0054 & 0.000525 & 0.06 \\
\hline Inhalation RfD & 0.000143 & & $5.71 \mathrm{E}-06$ & 0.0000286 & & & & & \\
\hline Inhalation SF & & 6.3 & 9.8 & 4.2 & & & 0.84 & & \\
\hline \multicolumn{10}{|l|}{ Burning } \\
\hline $\mathrm{HQ}_{\text {Ing }}$ & $6.03 \mathrm{E}-02$ & $6.64 \mathrm{E}-02$ & $1.44 \mathrm{E}-02$ & $3.76 \mathrm{E}-01$ & $4.88 \mathrm{E}-01$ & $5.70 \mathrm{E}-02$ & $7.18 \mathrm{E}-03$ & $5.01 \mathrm{E}+00$ & $4.14 \mathrm{E}-02$ \\
\hline $\mathrm{HQ}_{\text {Derm }}$ & $2.41 \mathrm{E}-03$ & $1.86 \mathrm{E}-02$ & $5.04 \mathrm{E}-05$ & $5.26 \mathrm{E}-02$ & $4.55 \mathrm{E}-03$ & $3.04 \mathrm{E}-03$ & 7.45E-05 & $9.35 \mathrm{E}-02$ & $5.79 \mathrm{E}-04$ \\
\hline LADD & & 5.18E-10 & & $8.79 \mathrm{E}-09$ & & & $1.12 \mathrm{E}-09$ & & \\
\hline \multicolumn{10}{|c|}{ Commercial Area } \\
\hline $\mathrm{HQ}_{\text {Ing }}$ & 4.64E-02 & $4.10 \mathrm{E}-03$ & $9.73 \mathrm{E}-03$ & $6.38 \mathrm{E}-01$ & $2.59 \mathrm{E}-02$ & $5.75 \mathrm{E}-03$ & $2.04 \mathrm{E}-03$ & $3.08 \mathrm{E}-01$ & $1.13 \mathrm{E}-02$ \\
\hline $\mathrm{HQ}_{\text {Derm }}$ & $1.85 \mathrm{E}-03$ & $1.15 \mathrm{E}-03$ & $3.41 \mathrm{E}-05$ & 8.93E-02 & $2.42 \mathrm{E}-04$ & $3.07 \mathrm{E}-04$ & $2.12 \mathrm{E}-05$ & $5.75 \mathrm{E}-03$ & $1.59 \mathrm{E}-04$ \\
\hline $\mathrm{HQ}_{\mathrm{Inh}}$ & $6.34 \mathrm{E}-04$ & $1.14 \mathrm{E}-05$ & $9.52 \mathrm{E}-04$ & $1.87 \mathrm{E}-03$ & $2.41 \mathrm{E}-06$ & $3.06 \mathrm{E}-06$ & $2.11 \mathrm{E}-07$ & $5.74 \mathrm{E}-05$ & $1.58 \mathrm{E}-06$ \\
\hline LADD & & $3.19 \mathrm{E}-11$ & & $1.49 \mathrm{E}-08$ & & & $2.67 \mathrm{E}-10$ & & \\
\hline \multicolumn{10}{|l|}{ Clinic } \\
\hline $\mathrm{HQ}_{\text {Ing }}$ & $5.46 \mathrm{E}-02$ & - & $9.35 \mathrm{E}-03$ & $2.61 \mathrm{E}-01$ & $6.69 \mathrm{E}-03$ & - & - & $1.05 \mathrm{E}-01$ & $4.83 \mathrm{E}-03$ \\
\hline $\mathrm{HQ}_{\text {Derm }}$ & $2.18 \mathrm{E}-03$ & _- & $3.27 \mathrm{E}-05$ & $3.66 \mathrm{E}-02$ & $6.24 \mathrm{E}-05$ & _ & _- & $1.96 \mathrm{E}-03$ & $6.77 \mathrm{E}-05$ \\
\hline LADD & & & & $6.11 \mathrm{E}-09$ & & & & & \\
\hline \multicolumn{10}{|l|}{ Dismantling } \\
\hline $\mathrm{HQ}_{\text {Ing }}$ & $7.38 \mathrm{E}-02$ & 5.13E-02 & $2.17 \mathrm{E}-02$ & $9.19 \mathrm{E}-01$ & $2.70 \mathrm{E}-01$ & $2.61 \mathrm{E}-02$ & $1.47 \mathrm{E}-02$ & $1.59 \mathrm{E}+00$ & $4.25 \mathrm{E}-02$ \\
\hline $\mathrm{HQ}_{\text {Derm }}$ & $2.95 \mathrm{E}-03$ & $1.44 \mathrm{E}-02$ & 7.61E-05 & $1.29 \mathrm{E}-01$ & $2.52 \mathrm{E}-03$ & $1.39 \mathrm{E}-03$ & $1.52 \mathrm{E}-04$ & $2.97 \mathrm{E}-02$ & $5.95 \mathrm{E}-04$ \\
\hline $\mathrm{HQ}_{\text {Inh }}$ & $1.01 \mathrm{E}-03$ & 1.43E-04 & 2.13E-03 & $2.69 \mathrm{E}-03$ & $2.52 \mathrm{E}-05$ & $1.39 \mathrm{E}-05$ & $1.52 \mathrm{E}-06$ & $2.96 \mathrm{E}-04$ & $5.94 \mathrm{E}-06$ \\
\hline LADD & & $4.00 \mathrm{E}-10$ & & $2.15 \mathrm{E}-08$ & & & $1.92 \mathrm{E}-09$ & & \\
\hline \multicolumn{10}{|l|}{ Farm } \\
\hline $\mathrm{HQ}_{\operatorname{Ing}}$ & $2.96 \mathrm{E}-02$ & $1.18 \mathrm{E}-03$ & $7.80 \mathrm{E}-03$ & 7.00E-01 & $1.50 \mathrm{E}-02$ & $8.22 \mathrm{E}-03$ & $1.60 \mathrm{E}-03$ & $2.70 \mathrm{E}-01$ & $5.94 \mathrm{E}-03$ \\
\hline $\mathrm{HQ}_{\text {Derm }}$ & $1.19 \mathrm{E}-03$ & 3.31E-04 & $2.73 \mathrm{E}-05$ & $9.80 \mathrm{E}-02$ & $1.40 \mathrm{E}-04$ & $4.38 \mathrm{E}-04$ & $1.66 \mathrm{E}-05$ & $5.03 \mathrm{E}-03$ & $8.32 \mathrm{E}-05$ \\
\hline $\mathrm{HQ}_{\text {Inh }}$ & 4.05E-04 & $3.31 \mathrm{E}-06$ & 7.64E-04 & $2.05 \mathrm{E}-03$ & $1.40 \mathrm{E}-06$ & $4.37 \mathrm{E}-06$ & $1.66 \mathrm{E}-07$ & $5.02 \mathrm{E}-05$ & $8.30 \mathrm{E}-07$ \\
\hline LADD & & $9.23 \mathrm{E}-12$ & & $1.64 \mathrm{E}-08$ & & & $2.10 \mathrm{E}-10$ & & \\
\hline \multicolumn{10}{|l|}{ Recreational } \\
\hline $\mathrm{HQ}_{\text {Ing }}$ & $4.17 \mathrm{E}-02$ & $1.23 \mathrm{E}-02$ & $1.20 \mathrm{E}-02$ & 7.42E-01 & $1.25 \mathrm{E}-01$ & $8.51 \mathrm{E}-03$ & $4.85 \mathrm{E}-03$ & $6.67 \mathrm{E}-01$ & $1.53 \mathrm{E}-02$ \\
\hline $\mathrm{HQ}_{\text {Derm }}$ & $1.67 \mathrm{E}-03$ & $3.44 \mathrm{E}-03$ & $4.20 \mathrm{E}-05$ & $1.04 \mathrm{E}-01$ & $1.17 \mathrm{E}-03$ & $4.54 \mathrm{E}-04$ & $5.03 \mathrm{E}-05$ & $1.25 \mathrm{E}-02$ & $2.15 \mathrm{E}-04$ \\
\hline $\mathrm{HQ}_{\text {Inh }}$ & $5.70 \mathrm{E}-04$ & $3.44 \mathrm{E}-05$ & $1.17 \mathrm{E}-03$ & $2.18 \mathrm{E}-03$ & $1.17 \mathrm{E}-05$ & 4.53E-06 & $5.02 \mathrm{E}-07$ & $1.24 \mathrm{E}-04$ & $2.14 \mathrm{E}-06$ \\
\hline LADD & & $9.59 \mathrm{E}-11$ & & $1.74 \mathrm{E}-08$ & & & $6.35 \mathrm{E}-10$ & & \\
\hline \multicolumn{10}{|l|}{ Residential } \\
\hline $\mathrm{HQ}_{\text {Ing }}$ & $6.18 \mathrm{E}-02$ & $1.73 \mathrm{E}-02$ & $1.69 \mathrm{E}-02$ & $3.37 \mathrm{E}-01$ & $2.23 \mathrm{E}-01$ & $2.69 \mathrm{E}-02$ & $8.94 \mathrm{E}-03$ & $1.68 \mathrm{E}+00$ & $2.57 \mathrm{E}-02$ \\
\hline LADD & & $1.35 \mathrm{E}-10$ & & 7.89E-09 & & & $1.17 \mathrm{E}-09$ & & \\
\hline \multicolumn{10}{|l|}{ School } \\
\hline $\mathrm{HQ}_{\text {Ing }}$ & $3.70 \mathrm{E}-02$ & $1.64 \mathrm{E}-03$ & $1.39 \mathrm{E}-02$ & $2.60 \mathrm{E}-01$ & $7.82 \mathrm{E}-03$ & $9.04 \mathrm{E}-03$ & $7.23 \mathrm{E}-04$ & $2.09 \mathrm{E}-01$ & $6.43 \mathrm{E}-03$ \\
\hline HQDerm & $1.48 \mathrm{E}-03$ & 4.60E-04 & $4.86 \mathrm{E}-05$ & $3.64 \mathrm{E}-02$ & $7.30 \mathrm{E}-05$ & $4.82 \mathrm{E}-04$ & 7.50E-06 & $3.90 \mathrm{E}-03$ & $9.00 \mathrm{E}-05$ \\
\hline $\mathrm{HQ}_{\mathrm{Inh}}$ & $5.07 \mathrm{E}-04$ & $4.59 \mathrm{E}-06$ & $1.36 \mathrm{E}-03$ & 7.63E-04 & $7.28 \mathrm{E}-07$ & $4.81 \mathrm{E}-06$ & 7.49E-08 & $3.89 \mathrm{E}-05$ & $8.98 \mathrm{E}-07$ \\
\hline LADD & & $1.28 \mathrm{E}-11$ & & $6.09 \mathrm{E}-09$ & & & $9.47 \mathrm{E}-11$ & & \\
\hline \multicolumn{10}{|l|}{ Worship } \\
\hline $\mathrm{HQ}_{\text {Ing }}$ & $7.36 \mathrm{E}-02$ & $1.97 \mathrm{E}-03$ & $1.00 \mathrm{E}-02$ & $4.05 \mathrm{E}-01$ & $1.94 \mathrm{E}-02$ & $7.12 \mathrm{E}-03$ & $1.62 \mathrm{E}-03$ & $2.20 \mathrm{E}-01$ & $9.20 \mathrm{E}-03$ \\
\hline $\mathrm{HQ}_{\text {Derm }}$ & $2.95 \mathrm{E}-03$ & $5.52 \mathrm{E}-04$ & $3.51 \mathrm{E}-05$ & $5.67 \mathrm{E}-02$ & $1.81 \mathrm{E}-04$ & $3.80 \mathrm{E}-04$ & $1.68 \mathrm{E}-05$ & $4.10 \mathrm{E}-03$ & $1.29 \mathrm{E}-04$ \\
\hline $\mathrm{HQ}_{\mathrm{Inh}}$ & $1.01 \mathrm{E}-03$ & 5.51E-06 & $9.82 \mathrm{E}-04$ & $1.19 \mathrm{E}-03$ & $1.81 \mathrm{E}-06$ & $3.79 \mathrm{E}-06$ & $1.68 \mathrm{E}-07$ & $4.09 \mathrm{E}-05$ & $1.29 \mathrm{E}-06$ \\
\hline LADD & & $1.54 \mathrm{E}-11$ & & $9.47 \mathrm{E}-09$ & & & $2.12 \mathrm{E}-10$ & & \\
\hline
\end{tabular}




\section{3-3-2- Non-Carcinogenic Health Risk of Heavy Metals}

The hazard indices for the non-carcinogenic risk obtained from a total of the hazard quotients are summarized in Table 3. The non-carcinogenic health hazard indices of $\mathrm{Ba}, \mathrm{Cd}, \mathrm{Co}, \mathrm{Ni}$ and $\mathrm{Zn}$ for children under 6 years in all study areas within the AEPS were below the 1 reference limit of environmental and regulatory agencies below which hazards are considered acceptable for children. The values however of $\mathrm{Cr}$ and $\mathrm{Hg}$ in some areas (Burning, Dismantling and Residential) were above the 1 regulatory limit and considered unacceptable by environmental and healthcare managers. For instance hazard index for $\mathrm{Pb}$ in the burning was $500 \%$ above the reference limit for which exposure if contacted by children in high doses, can trigger neurological and developmental disorders [11,12]. Further, despite the low health hazard indices of $\mathrm{Ba}, \mathrm{Cd}, \mathrm{Co}, \mathrm{Ni}$ and $\mathrm{Zn}$ in all AEPS sites, these heavy metals can be cumulative and can affect the kidney and other vital human organs, and as such their exposure to children must be avoided [27].

Table 3. Non-carcinogenic hazard indices

\begin{tabular}{lccccccccc}
\hline Area & Ba & $\mathbf{C d}$ & $\mathbf{C o}$ & $\mathbf{C r}$ & $\mathbf{C u}$ & $\mathbf{H g}$ & $\mathbf{N i}$ & $\mathbf{P b}$ & $\mathbf{Z n}$ \\
\hline Burning & 0.063 & 0.085 & 0.016 & 0.430 & 0.492 & 1.323 & 0.007 & 5.104 & 0.042 \\
Commercial Area & 0.049 & 0.005 & 0.011 & 0.729 & 0.026 & 0.134 & 0.002 & 0.314 & 0.011 \\
Clinic & 0.058 & - & 0.01 & 0.299 & 0.007 & - & - & 0.107 & 0.005 \\
Dismantling & 0.078 & 0.066 & 0.024 & 1.050 & 0.273 & 0.605 & 0.150 & 1.621 & 0.043 \\
Farm & 0.081 & 0.002 & 0.009 & 0.800 & 0.015 & 0.191 & 0.002 & 0.275 & 0.006 \\
Recreational & 0.044 & 0.016 & 0.013 & 0.848 & 0.127 & 0.197 & 0.005 & 0.68 & 0.016 \\
Residential & 0.065 & 0.022 & 0.019 & 0.385 & 0.225 & 0.625 & 0.009 & 1.715 & 0.026 \\
School & 0.039 & 0.002 & 0.015 & 0.297 & 0.008 & 0.210 & 0.001 & 0.213 & 0.007 \\
Worship & 0.078 & 0.003 & 0.011 & 0.463 & 0.020 & 0.165 & 0.002 & 0.224 & 0.009 \\
\hline
\end{tabular}

\section{3-3-3- Carcinogenic Health Risk of Heavy Metals}

The carcinogenic risk was calculated as product of inhalation slope factor and the life average daily dosage based on the risk through inhalation for four carcinogenic heavy metals $(\mathrm{Cd}, \mathrm{Cr}$ and $\mathrm{Ni}$ ) using the model as expressed in Equation 8. The carcinogenic risk of these heavy metals due to activities within the AEPS is low, as it is below the threshold range of values $10^{-4}$ and $10^{-6}$ (Table 4 . The cancer hazard index of these metals is in the order $\mathrm{Cr}>\mathrm{Cd}>\mathrm{Ni}$ with risk indices of $\mathrm{Cd}$ and $\mathrm{Ni}$ alternating depending on the site. Although hazard indices for the 3 carcinogenic heavy metals of $\mathrm{Cd}, \mathrm{Cr}$ and $\mathrm{Ni}$ were all below the threshold range for which the hazard is acceptable, the risk index for $\mathrm{Cr}$ in all areas cannot be overlooked as is the closest to the threshold value and further accumulation without an intervention can be detrimental to health of children and adults.

Table 4. Carcinogenic hazard indices of heavy metals

\begin{tabular}{lccc}
\hline Area & $\mathbf{C d}$ & $\mathbf{C r}$ & $\mathbf{N i}$ \\
\hline Burning & $3.26 \mathrm{E}-09$ & $3.69 \mathrm{E}-07$ & $9.41 \mathrm{E}-10$ \\
Commercial Area & $2.01 \mathrm{E}-10$ & $6.26 \mathrm{E}-07$ & $2.67 \mathrm{E}-10$ \\
Clinics & - & $2.57 \mathrm{E}-07$ & - \\
Dismantling & $2.52 \mathrm{E}-09$ & $9.03 \mathrm{E}-07$ & $1.92 \mathrm{E}-09$ \\
Farm & $5.81 \mathrm{E}-11$ & $6.87 \mathrm{E}-07$ & $2.1 \mathrm{E}-10$ \\
Recreational & $6.04 \mathrm{E}-10$ & $7.29 \mathrm{E}-07$ & $6.35 \mathrm{E}-10$ \\
Residential & $8.48 \mathrm{E}-10$ & $3.31 \mathrm{E}-07$ & $1.17 \mathrm{E}-09$ \\
School & $8.07 \mathrm{E}-11$ & $2.56 \mathrm{E}-07$ & $9.47 \mathrm{E}-11$ \\
Worship & $9.69 \mathrm{E}-11$ & $3.98 \mathrm{E}-07$ & $2.12 \mathrm{E}-10$ \\
\hline
\end{tabular}

\section{4- Conclusion}

Heavy metal contamination as a result of e-waste recycling presents a significant threat to the environment, workers and residents of the Agbogbloshie e-waste processing site. This paper assessed the extent of contamination and health risk posed by $\mathrm{Ba}, \mathrm{Cd}, \mathrm{Co}, \mathrm{Cr}, \mathrm{Cu}, \mathrm{Hg}, \mathrm{Ni}, \mathrm{Pb}$ and $\mathrm{Zn}$ heavy metals within the AEPS. From 132 soil sample locations, heavy metal concentrations were measured, contamination factor of each heavy metal estimated, degree of contamination calculated and the health risk evaluated.

In general, heavy metal concentrations in soils from the study area were highest in the main working areas burning 
and dismantling sites of informal e-waste recyclers and mean concentrations of $\mathrm{Cd}, \mathrm{Cr}$ and $\mathrm{Ni}$ considered as carcinogenic and $\mathrm{Hg}$ from all sites within the AEPS were lower than the Dutch and Canadian soil regulatory limit but those of $\mathrm{Cu}$, $\mathrm{Pb}$ and $\mathrm{Zn}$ considered non-carcinogenic had mean concentrations between 100-500\% higher than regulatory limits of Dutch and Canadian soil standards. Analysis of contamination factor of individual heavy metal in soil from AEPS showed $\mathrm{Ni}<\mathrm{Ba}<\mathrm{Co}<\mathrm{Cr}<\mathrm{Zn}<\mathrm{Hg}<\mathrm{Cu}<\mathrm{Cd}<\mathrm{Pb}$ in an increasing order as contributing to the degree of contamination. According to the degree of contamination index classification, the burning, dismantling, residential, recreational and commercial areas within the AEPS represented highly contaminated sites.

Further analysis of possible health risk due to exposure of heavy metals to children under 6 years suggests children are not at significant potential carcinogenic health risk from intake of $\mathrm{Cd}, \mathrm{Cr}$ and $\mathrm{Ni}$ but there is significant potential non-carcinogenic health risk due to exposure of $\mathrm{Cr}, \mathrm{Cu}, \mathrm{Hg}$ and $\mathrm{Pb}$ with hazard indexes in the burning and dismantling areas above reference value of 1 and can cause developmental and neurological disorders in children.

\section{5- Acknowledgments}

The authors would like to thank the Department of Chemistry, Kwame Nkrumah University of Science and Technology, Kumasi for their technical assistance and support.

\section{6- Conflict of Interest}

The authors declare no conflict of interest.

\section{7- References}

[1] Kılıç Altun, S., Dinç, H., Paksoy, N., Temamoğulları, F. K., and Savrunlu, M. "Analyses of mineral content and heavy metal of honey samples from South and East Region of Turkey by using ICP-MS." International Journal of Analytical Chemistry 2017, no. (2017): 1-6. doi:10.1155/2017/6391454.

[2] Maus, C. "The impact on environmental stressors on apiculture in Africa." Bulletin of Animal Health and Production in Africa 64, no. 1 (2016): 37-48.

[3] Moinde, J. "The status and future prospects of honeybee production in Africa." Bulletin of Animal Health and Production in Africa 64, no. 1 (2016): 169-182.

[4] González-Miret, M. L., Terrab, A., Hernanz, D., Fernández-Recamales, M. Á., and Heredia, F. J. "Multivariate correlation between color and mineral composition of honeys and by their botanical origin." Journal of Agricultural and Food Chemistry 53, no. 7 (2005): 2574-2580. doi:10.1021/jf048207p.

[5] Ahmida, M. H., Elwerfali, S., Agha, A., Elagori, M., and Ahmida, N. H. "Physicochemical, heavy metals and phenolic compounds analysis of Libyan honey samples collected from Benghazi during 2009-2010." Food and Nutrition Sciences 4, no. 1 (2013): 3340.

[6] Anklam, E. "A review of the analytical methods to determine the geographical and botanical origin of honey." Food Chemistry 63, no. 4 (1998): 549-562. doi:10.1016/S0308-8146(98)00057-0.

[7] da C Azeredo, L., Azeredo, M., De Souza, S., and Dutra, V. "Protein contents and physicochemical properties in honey samples of Apis mellifera of different floral origins." Food Chemistry 80, no. 2 (2003): 249-254. doi:10.1016/S0308-8146(02)00261-3.

[8] Serbula, S. M., Kalinovic, T. S., Ilic, A. A., Kalinovic, J. V., and Steharnik, M. M. "Assessment of airborne heavy metal pollution using Pinus spp. and Tilia spp." Aerosol Air Qual Res 13, no. 2 (2013): 563-573. doi:10.4209/aaqr.2012.06.0153.

[9] Wang, J., Kliks, M. M., Jun, S., and Li, Q. X. "Residues of organochlorine pesticides in honeys from different geographic regions." Food Research International 43, no. 9 (2010): 2329-2334. doi:10.1016/j.foodres.2010.08.006.

[10] Ru, Q.-M., Feng, Q., and He, J.-Z. "Risk assessment of heavy metals in honey consumed in Zhejiang province, south-eastern China." Food and Chemical Toxicology 53, no. (2013): 256-262. doi:10.1016/j.fct.2012.12.015.

[11] Sun, F., Wen, D., Kuang, Y., Li, J., Li, J., and Zuo, W. "Concentrations of heavy metals and polycyclic aromatic hydrocarbons in needles of Masson pine (Pinus massoniana L.) Growing nearby different industrial sources." Journal of Environmental Sciences 22, no. 7 (2010): 1006-1013. doi:10.1016/S1001-0742(09)60211-4.

[12] Oroian, M., Prisacaru, A., Hretcanu, E. C., Stroe, S.-G., Leahu, A., and Buculei, A. "Heavy metals profile in honey as a potential indicator of botanical and geographical origin." International Journal of Food Properties 19, no. 8 (2016): 1825-1836. doi:10.1080/10942912.2015.1107578. 
[13] Matin, G., Kargar, N., and Buyukisik, H. B. "Bio-monitoring of cadmium, lead, arsenic and mercury in industrial districts of Izmir, Turkey by using honey bees, propolis and pine tree leaves." Ecological Engineering 90, no. (2016): 331-335. doi:10.1016/j.ecoleng.2016.01.035.

[14] Conti, M. E., and Botrè, F. "Honeybees and their products as potential bioindicators of heavy metals contamination." Environmental Monitoring and Assessment 69, no. 3 (2001): 267-282. doi:10.1023/A:1010719107006.

[15] Finger, D., Kelte Filho, I., Torres, Y. R., and Quináia, S. P. "Propolis as an indicator of environmental contamination by metals." Bulletin of Environmental Contamination and Toxicology 92, no. 3 (2014): 259-264. doi:10.1007/s00128-014-1199-4.

[16] Han, P., Niu, C.-Y., Lei, C.-L., Cui, J.-J., and Desneux, N. "Quantification of toxins in a Cry1 Ac+ CpTI cotton cultivar and its potential effects on the honey bee Apis mellifera L." Ecotoxicology 19, no. 8 (2010): 1452-1459. doi:10.1007/s10646-010-0530$\mathrm{z}$.

[17] Bilandžić, N., Đokić, M., Sedak, M., Kolanović, B. S., Varenina, I., Končurat, A., and Rudan, N. "Determination of trace elements in Croatian floral honey originating from different regions." Food Chemistry 128, no. 4 (2011): 1160-1164. doi:10.1016/j.foodchem.2011.04.023.

[18] Erbilir, F., and Erdoĝrul, Ö. "Determination of heavy metals in honey in Kahramanmaraş City, Turkey." Environmental Monitoring and Assessment 109, no. 1-3 (2005): 181-187. doi:10.1007/s10661-005-5848-2.

[19] Kováčik, J., Grúz, J., Biba, O., and Hedbavny, J. "Content of metals and metabolites in honey originated from the vicinity of industrial town Košice (eastern Slovakia)." Environmental Science and Pollution Research 23, no. 5 (2016): 4531-4540. doi:10.1007/s11356-015-5627-8.

[20] Stankovska, E., Stafilov, T., and Šajn, R. "Monitoring of trace elements in honey from the Republic of Macedonia by atomic absorption spectrometry." Environmental Monitoring and Assessment 142, no. 1-3 (2008): 117-126. doi:10.1007/s10661-0079913-x.

[21] Chua, L. S., Abdul-Rahaman, N.-L., Sarmidi, M. R., and Aziz, R. "Multi-elemental composition and physical properties of honey samples from Malaysia." Food Chemistry 135, no. 3 (2012): 880-887. doi:10.1016/j.foodchem.2012.05.106.

[22] Aidoo, K. The honey trade in Ghana. In: Proceedings of a paper presented at the bees for development honey trade workshop held in Dublin, Ireland in August, 2005.

[23] Solayman, M., Islam, M., Paul, S., Ali, Y., Khalil, M., Alam, N., and Gan, S. H. "Physicochemical properties, minerals, trace elements, and heavy metals in honey of different origins: a comprehensive review." Comprehensive Reviews in Food Science and Food Safety 15, no. 1 (2016): 219-233. doi:10.1111/1541-4337.12182.

[24] Nickel, E. "The definition of a mineral." Mineral J 17, no. 7 (1995): 346-349

[25] Tuyen, L. D., Hien, V. T. T., Binh, P. T., and Yamamoto, S. "Calcium and vitamin D deficiency in vietnamese: recommendations for an intervention strategy." Journal of Nutritional Science and Vitaminology 62, no. 1 (2016): 1-5. doi:10.3177/jnsv.62.1.

[26] Moniruzzaman, M., Chowdhury, M. A. Z., Rahman, M. A., Sulaiman, S. A., and Gan, S. H. "Determination of mineral, trace element, and pesticide levels in honey samples originating from different regions of Malaysia compared to Manuka honey." BioMed research international 2014, no. (2014): 1-10. doi:10.1155/2014/359890.

[27] Downey, G., Hussey, K., Kelly, J. D., Walshe, T. F., and Martin, P. "Preliminary contribution to the characterisation of artisanal honey produced on the island of Ireland by palynological and physico-chemical data." Food Chemistry 91, no. 2 (2005): 347354. doi:10.1016/j.foodchem.2004.06.020.

[28] Conti, M. E. "Lazio region (central Italy) honeys: a survey of mineral content and typical quality parameters." Food Control 11, no. 6 (2000): 459-463. doi:10.1016/S0956-7135(00)00011-6.

[29] Pisani, A., Protano, G., and Riccobono, F. "Minor and trace elements in different honey types produced in Siena County (Italy)." Food Chemistry 107, no. 4 (2008): 1553-1560. doi:10.1016/j.foodchem.2007.09.029.

[30] Fernández-Torres, R., Perez-Bernal, J. L., Bello-Lopez, M. A., Callejon-Mochon, M., Jimenez-Sanchez, J. C., and GuiraúmPérez, A. "Mineral content and botanical origin of Spanish honeys." Talanta 65, no. 3 (2005): 686-691. doi:10.1016/j.talanta.2004.07.030.

[31] Yilmaz, H., and Yavuz, Ö. "Content of some trace metals in honey from south-eastern Anatolia." Food Chemistry 65, no. 4 (1999): 475-476. doi:10.1016/S0308-8146(98)00205-2.

[32] Dhahir, S. A., and Hemed, A. H. "Determination of heavy metals and trace element levels in honey samples from different regions of Iraq and compared with other kind." American Journal of Applied Chemistry 3, no. 3 (2015): 83-92. doi:10.11648/j.ajac.20150303.11. 
[33] Terrab, A., Recamales, A. F., Gonzalez-Miret, M. L., and Heredia, F. J. "Contribution to the study of avocado honeys by their mineral contents using inductively coupled plasma optical emission spectrometry." Food Chemistry 92, no. 2 (2005): 305-309. doi:10.1016/j.foodchem.2004.07.033.

[34] Silva, L. R., Videira, R., Monteiro, A. P., Valentão, P., and Andrade, P. B. "Honey from Luso region (Portugal): Physicochemical characteristics and mineral contents." Microchemical Journal 93, no. 1 (2009): 73-77. doi:10.1016/j.microc.2009.05.005.

[35] Pohl, P. "Determination of metal content in honey by atomic absorption and emission spectrometries." TRAC Trends in Analytical Chemistry 28, no. 1 (2009): 117-128. doi:10.1016/j.trac.2008.09.015.

[36] Bagchi, D. "Nutraceutical and functional food regulations in the United States and around the world ". USA: Elsevier Incorporated, 2008.

[37] Tuzen, M., Silici, S., Mendil, D., and Soylak, M. "Trace element levels in honeys from different regions of Turkey." Food Chemistry 103, no. 2 (2007): 325-330. doi:10.1016/j.foodchem.2006.07.053.

[38] Zhelyazkova, I. "Honeybees-bioindicators for environmental quality." Bulgarian journal of agricultural science 18, no. 3 (2012): 435-442.

[39] White Jr, J. W. "Composition of Honey ". Honey: A Comprehensive Survey. London: Heinemann, 1975.

[40] Lagnika, L., Amoussa, A. M. O., Oketokoun, S. A., Adjovi, Y., and Sanni, A. "In vitro antifungal and antioxidant activities of two Benin medicinal plants." Journal of Medicinal Plants Research 8, no. 12 (2014): 513-519. doi:10.5897/JMPR2014.5383.

[41] Chowdhury, M. A., Abdellatif, K. R., Dong, Y., Das, D., Suresh, M. R., and Knaus, E. E. "Synthesis of celecoxib analogues possessing a N-difluoromethyl-1, 2-dihydropyrid-2-one 5-lipoxygenase pharmacophore: biological evaluation as dual inhibitors of cyclooxygenases and 5-lipoxygenase with anti-inflammatory activity." Journal of Medicinal Chemistry 52, no. 6 (2009): 1525-1529. doi:10.1021/jm8015188.

[42] Yuliana, F. "Stability study of antibacterial activity of mixed lime juice and honey of heating temperature on Staphylococcusaureus and Streptococcuspyogenes." International Journal of Pure and Applied Sciences and Technology 21, no. 2 (2014): 1-7.

[43] Grover, V., Babu, R., and Bedi, S. "Steroid therapy-current indications in practice." Indian Journal of Anaesthesia 51, no. 5 (2007): 389- 